\title{
Inconsistent decadal variations between surface and free tropospheric nitrogen oxides over United States
}

Zhe Jiang ${ }^{1}$, Helen Worden ${ }^{1}$, John R. Worden ${ }^{2}$, Daven K. Henze ${ }^{3}$, Dylan B. A. Jones ${ }^{4}$, Avelino F. Arellano ${ }^{5}$, Emily V. Fischer ${ }^{6}$, Liye Zhu ${ }^{6}$, Kazuyuki Miyazaki ${ }^{2,7}$, K. Folkert Boersma ${ }^{8,9}$, Vivienne H. Payne ${ }^{2}$,

${ }^{1}$ National Center for Atmospheric Research, Boulder, CO, USA

${ }^{2}$ Jet Propulsion Laboratory, California Institute of Technology, Pasadena, CA, USA

${ }^{3}$ Department of Mechanical Engineering, University of Colorado, Boulder, CO, USA

${ }^{4}$ Department of Physics, University of Toronto, Toronto, ON, Canada

${ }^{5}$ Department of Hydrology and Atmospheric Sciences, University of Arizona, Tucson, AZ, USA

${ }^{6}$ Department of Atmospheric Science, Colorado State University, Fort Collins, CO, USA

${ }^{7} J a p a n$ Agency for Marine-Earth Science and Technology, Yokohama, Japan

${ }^{8}$ Wageningen University, Meteorological and Air Quality department, Wageningen, the Netherlands

${ }^{9}$ Royal Netherlands Meteorological Institute, De Bilt, The Netherlands 


\section{Abstract}

Decreases in surface emissions of nitrogen oxides $\left(\mathrm{NO}_{\mathrm{x}}=\mathrm{NO}+\mathrm{NO}_{2}\right)$ in North America have led to substantial improvements in air-quality over the last several decades. Here we show that satellite observations of tropospheric nitrogen dioxide $\left(\mathrm{NO}_{2}\right)$ columns over the contiguous United States (US) do not decrease after about 2009, while surface $\mathrm{NO}_{2}$ concentrations continue to decline through to the present. This divergence, if it continues, could have a substantial impact on surface air quality due to mixing of free-tropospheric air into the boundary layer. Our results show only

41 limited contributions from local effects such as fossil fuel emissions, lightning, or instrument

42 artifacts, but we do find a possible relationship of $\mathrm{NO}_{2}$ changes to decadal climate variability. Our analysis demonstrates that the intensity of transpacific transport is stronger in El Niño years and weaker in La Niña years, and consequently, that decadal-scale climate variability impacts the contribution of Asian emissions on North American atmospheric composition. Because of the short lifetime, it is usually believed that the direct contribution of long-range transport to tropospheric $\mathrm{NO}_{\mathrm{x}}$ distribution is limited. If our hypothesis about transported Asian emissions is correct, then this observed divergence between satellite and surface $\mathrm{NO}_{\mathrm{x}}$ could indicate mechanisms that allow for either $\mathrm{NO}_{\mathrm{x}}$ or its reservoir species to have a larger than expected effect on North American tropospheric composition. These results therefore suggest more aircraft and satellite studies to

51 determine the possible missing processes in our understanding of the long-range transport of 52 tropospheric $\mathrm{NO}_{\mathrm{x}}$.

\section{Introduction}

Nitrogen oxides play a complex role in tropospheric chemistry and have a strong influence

56 on air quality as precursors in the formation of ozone $\left(\mathrm{O}_{3}\right)$ and secondary aerosols. Tropospheric 
$\mathrm{NO}_{\mathrm{x}}$ is produced through anthropogenic combustion, biomass burning, soil (Jaegle et al., 2005), and lightning emissions (Schumann and Huntrieser, 2007), and is mainly removed by the formation of nitric acid $\left(\mathrm{HNO}_{3}\right)$. Most $\mathrm{NO}_{\mathrm{x}}$ is emitted as nitric oxide (NO), however, it is most appropriate to consider the budget of the $\mathrm{NO}_{\mathrm{x}}$ as a whole, because of the rapid cycling between $\mathrm{NO}$ and $\mathrm{NO}_{2}(\sim 1 \mathrm{~min})$. Tropospheric $\mathrm{NO}_{\mathrm{x}}$ has short lifetime, a few hours except in extratropical winter when it increases to 1-2 days (Martin et al. 2003). direct contribution of long-range transport to tropospheric $\mathrm{NO}_{\mathrm{x}}$ distribution is limited (e.g. Zhang et al. 2008). However, $\mathrm{NO}_{\mathrm{x}}$ can also be transported far away from the sources via the formation of long-lived reservoir species, such as peroxyacetyl nitrate (PAN, e.g., Fischer et al., 2014; Jiang et al. 2016a). Models have large uncertainties in PAN abundance (Fischer et al., 2014) and there are also potentially other missing processes in the chemical transport models used to diagnose $\mathrm{NO}_{\mathrm{x}}$ lifetime and transport. For example, a recent discovery about the rapid cycling of reactive nitrogen in the marine boundary layer (Ye et al. 2016) demonstrates processes that are not represented in modeled $\mathrm{NO}_{\mathrm{x}}$ transport, and that may help explain existing discrepancies in reactive nitrogen partitioning between models and observations.

Due to its critical influence in the troposphere, there are multiple space-based measurements for tropospheric $\mathrm{NO}_{2}$ that are available from satellites that were launched in the past two decades. These instruments typically measure backscattered solar radiation from which the vertically integrated column abundance of $\mathrm{NO}_{2}$ is retrieved. The assumption of weak long-range transport allows relatively simple applications of the space-based $\mathrm{NO}_{2}$ column data to study $\mathrm{NO}_{\mathrm{x}}$ sources. For example, recent studies (e.g. Reuter et al. 2014; Itahashi et al. 2014; Duncan et al. 
correlation between tropospheric $\mathrm{NO}_{2}$ columns with local emissions. The tropospheric $\mathrm{NO}_{2}$ column data are also widely used in inverse modeling analyses to estimate $\mathrm{NO}_{\mathrm{x}}$ emissions by either scaling the surface $\mathrm{NO}_{\mathrm{x}}$ emissions with the corresponding ratio of observed over modeled tropospheric $\mathrm{NO}_{2}$ column (e.g. Lamsal et al. 2011; Mijling et al. 2012; Gu et al. 2014) or through data assimilation techniques with short localization length scales (e.g. Miyazaki et al. 2017). regions (US Environmental Protection Agency, 2010). The trend of decreasing local US $\mathrm{NO}_{\mathrm{x}}$ emissions has been confirmed by several studies (e.g. Lamsal et al. 2015; Tong et al. 2015; Kharol et al. 2015; Duncan et al. 2016; Krotkov et al. 2016). In contrast to the decreasing local $\mathrm{NO}_{\mathrm{x}}$ emissions, recent studies (e.g. Cooper et al. 2010; Verstraeten et al. 2015) have indicated an increase in free tropospheric $\mathrm{O}_{3}$ over western North America over the past decade. The discrepancy between variations of local $\mathrm{NO}_{\mathrm{x}}$ emissions and free tropospheric $\mathrm{O}_{3}$ suggests possible influences from non-local sources, and consequently, provides motivation to re-evaluate the contribution of long-range transport to the free tropospheric $\mathrm{NO}_{\mathrm{x}}$ distribution.

In this work, we investigate the variation of US tropospheric $\mathrm{NO}_{2}$ in the past decade to assess the contribution of non-local sources. We will particularly explore the possible answers for the following questions: why there is good agreement between tropospheric $\mathrm{NO}_{2}$ column and surface measurements over the period of 2005-2008? What is the reason for the appearance of the large and growing divergence at around 2009? What is the impact of the decreasing Chinese $\mathrm{NO}_{\mathrm{x}}$ emissions since 2013 (Liu et al. 2016) on North America? To evaluate these critical questions, multiple data sets and model are used in this work, including remotely sensed $\mathrm{NO}_{2}$ column measurements from Ozone Monitoring Instrument (OMI, NASA and DOMINO products), in-situ 

network, flash rate density data from Lightning Imaging Sensor (LIS), and the GEOS-Chem chemical transport model. used in this work. In Section 3 we demonstrate the divergence between the $\mathrm{OMI} \mathrm{NO}_{2}$ column retrievals and surface measurements over the period of 2005-2015 and focus on the evaluation of contributions from various hypotheses that could explain the divergence. Our conclusions follow in Section 4.

\section{Observations and Models}

\subsection{Tropospheric $\mathrm{NO}_{2}$ column from $\mathrm{OMI}$}

The OMI instrument was launched on NASA's Aura spacecraft. The sensor has a spatial resolution of $13 \mathrm{~km} \times 24 \mathrm{~km}$. OMI provides daily global coverage with measurements of both direct and atmosphere-backscattered sunlight in the ultraviolet-visible range from 270 to $500 \mathrm{~nm}$;

116 the spectral range $405-465 \mathrm{~nm}$ is used to retrieve tropospheric $\mathrm{NO}_{2}$ columns. Two versions of the

117 OMI retrievals (level 2) are used in this work: the NASA (version 3, Krotkov and Veefkind 2006;

118 Bucsela et al. 2013) and DOMINO (version 2, Boersma et al. 2011) retrievals. There are significant

119 differences in the retrieval algorithms of the two products. For example, the a priori $\mathrm{NO}_{2}$ profiles

120 of the NASA product is based on data from the Global Modeling Initiative (GMI) model with

121 yearly varying emissions, whereas the a priori $\mathrm{NO}_{2}$ profiles of the DOMINO product is from the

122 Tracer Model 4 (TM4) without interannual variations in emissions. In addition, for the NASA

123 product, the stratospheric contribution to the tropospheric column is estimated from the GMI

124 model simulation. In contrast, for the DOMINO product, the stratospheric contribution is based on

125 the assimilation of OMI data into the TM4 model. 

radiances in certain cross-track positions. This instrument degradation has been referred to as the

128 "row anomaly". In order to ensure the quality and stability of the data, the following filters are applied in our analysis for both OMI products (NASA and DOMINO):

After the application of the filters, the number of measurements over the US is about 185,000 per month in 2010. Thus, we expect the uncertainties in the monthly/annual mean $\mathrm{NO}_{2}$ columns due to random errors are small. The discrepancy between the two OMI products (see Figures 1a-b) is mainly caused by the two different retrieval algorithms.

\subsection{AQS and NAPS surface in-situ $\mathrm{NO}_{2}$ concentration}

We use daily-averaged in-situ surface $\mathrm{NO}_{2}$ measurements from the EPA AQS network, and the Environment Canada NAPS network. The AQS/NAPS networks collect ambient air pollution data from monitoring stations located in urban, suburban, and rural areas. In the analysis here, the daily data are averaged to obtain monthly mean concentration at each station.

\subsection{Flash rate density from Lightning Imaging Sensor (LIS)} total optical pulses from cloud-to-ground and intracloud lightning flashes during both day and night with global coverage $\left(42.5^{\circ} \mathrm{S}-42.5^{\circ} \mathrm{N}\right)$ in the period $1995-2014$. Monthly flash rate density 


\subsection{NOAA Niño 3.4 index}

The Niño 3.4 index comprises sea surface temperature averaged across the region $\left(5^{\circ} \mathrm{S}-\right.$ $5^{\circ} \mathrm{N}, 170^{\circ} \mathrm{W}-120^{\circ} \mathrm{W}$ ), and their monthly anomalies relative to the $1982-2015$ means to constitute the indices. Years with positive values $(>0.5)$ are considered as El Niño, whereas years with negative values $(<-0.5)$ are considered as La Niña.

\subsection{Passive tracer simulation using GEOS-Chem model}

The GEOS-Chem global chemical transport model (CTM) [www.geos-chem.org] is driven by assimilated meteorological fields (MERRA) from the NASA Goddard Earth Observing System at the Global Modeling and data Assimilation Office. We use version v9-01-03 of GEOS-Chem at a horizontal resolution of $4^{\circ} \times 5^{\circ}$. Bertram et al. (2013) indicated the dominant role of long-lived reservoir species in the transpacific transport of reactive nitrogen using aircraft measurements from the INTEX-B campaign. Although the lifetime of tropospheric $\mathrm{NO}_{\mathrm{x}}$ is short, the lifetime of longlived reservoir species is much longer, for example, the lifetime of free tropospheric PAN is about 1 month. In order to assess the effects of physical transport processes on the long-range transport of reactive nitrogen, we performed a "passive" tracer simulation, with a constant and uniform timescale for loss of 15 days (i.e. 360 hours) over the period of 2005-2015 following the approach of Jiang et al. (2016b). The global a priori surface $\mathrm{NO}_{\mathrm{x}}$ emissions (anthropogenic, biomass burning and soil emissions) are fixed at 2005 level. For each time step (one hour), the tropospheric $\mathrm{NO}_{2}$ is

167 calculated by: $N O_{2}^{t}=N O_{2}^{t-1} e^{-1 / 360}$. The lightning $\mathrm{NO}_{\mathrm{x}}$ emissions are not included in the 168 simulation. The 15-day lifetime was selected to provide an approximation for the variation of free 169 tropospheric $\mathrm{NO}_{\mathrm{x}}$ via the formation and transport of long-lived reservoir species, due to changes 170 in meteorology. Although actual lifetimes of long-lived reservoir species will vary, we found that 171 15-days was a reasonable compromise to understand the influence of decadal-scale variability on 
long-range transport patterns.

\section{3}

\section{Results and Discussion}

Figures $1 \mathrm{a}-\mathrm{b}$ show the variations of mean tropospheric $\mathrm{NO}_{2}$ columns from OMI (NASA and DOMINO products) over the US and east China, respectively. Although there is a significant bias in the magnitude of tropospheric $\mathrm{NO}_{2}$ column between two OMI products, indicating the influence of different retrieval algorithms, this bias should not affect the trend analysis, as demonstrated by the consistent interannual variations between the two data products. Figure 1c shows percent changes, relative to 2009 , of the annual mean tropospheric $\mathrm{NO}_{2}$ columns over the US, and of the total US $\mathrm{NO}_{\mathrm{x}}$ emissions (anthropogenic + biomass burning) from the US EPA (https://www.epa.gov/air-emissions-inventories/air-pollutant-emissions-trends-data). There is good agreement between the changes in the OMI retrievals and the emissions estimates in the 2005-2009 period: the annual slope of the EPA's estimates is $-6.4 \% \pm 0.03 \%$ (slope of linear regression \pm uncertainty of slope), and the annual slopes of the two sets of OMI retrievals are $6.8 \% \pm 1.1 \%$ (NASA) and $-8.0 \% \pm 0.8 \%$ (DOMINO). Conversely, we find a large, growing separation in the $2009-2015$ period: the annual slope of the EPA's estimates is $-4.6 \% \pm 0.03 \%$, whereas the annual slopes of OMI retrievals are $-0.5 \% \pm 0.6 \%$ (NASA) and $1.6 \% \pm 1.1 \%$ (DOMINO). Figures 1d-e show the percent changes in the seasonal mean tropospheric $\mathrm{NO}_{2}$ columns from OMI retrievals, and in the EPA's estimates (annual mean). The divergence between the seasonal $\mathrm{NO}_{2}$ columns and the emissions is similar to that shown in Figure 1c, suggesting there is no obvious seasonal dependence.

Our intention here is to understand the possible reasons for the divergence between observed changes in $\mathrm{NO}_{2}$ vs. changes expected from $\mathrm{NO}_{\mathrm{x}}$ emissions. Figure 2 depicts the potential hypotheses that could explain the divergence: 
- Hypothesis 2 (H2): Time dependent OMI retrieval errors

- Hypothesis 3 (H3): Non-local sources

\subsection{Increasing local $\mathrm{NO}_{\mathrm{x}}$ emissions (H1)}

Figure 3a shows the differences of mean surface $\mathrm{NO}_{2}$ concentrations, as measured by the AQS and NAPS network, from 2009-2010 to 2014-2015. These time periods were chosen to determine changes in surface $\mathrm{NO}_{2}$ concentrations over the period of 2009-2015 with sufficient stattistics. Figure $3 \mathrm{~b}$ shows the same variations averaged with $4^{\circ} \times 5^{\circ}$ resolution (i.e., at the GEOSChem grid points). The surface stations demonstrate dramatic decreases of surface $\mathrm{NO}_{2}$ concentrations in the period of 2009-2015. The consistent decreasing trends in the surface $\mathrm{NO}_{2}$ concentrations and the EPA's emission estimates during the period of 2009-2015 suggests that the divergence between the OMI retrievals and the EPA's emission estimates is not caused by US local emissions. We note that our analysis based on surface in-situ measurements may not provide sufficient representation for emissions from oil and gas exploration and production. However, though potentially important locally, these activities only contribute about $5 \%$ to total US $\mathrm{NO}_{\mathrm{x}}$ emissions based on EPA's estimates. Therefore, we do not expect significant contributions to the overall changes in tropospheric $\mathrm{NO}_{2}$ from these sources.

Similarly, we expect limited contributions from other sources which are not included in EPA's inventory. The contribution from aircraft $\mathrm{NO}_{\mathrm{x}}$ is only about $3 \%$ of total $\mathrm{US}_{\mathrm{NO}}$ emissions (Skowron et al. 2014). Soil $\mathrm{NO}_{\mathrm{x}}$ emissions account for up to $40 \%$ of the tropospheric $\mathrm{NO}_{2}$ columns in summer over US rural areas (Hudman et al. 2010), but only contribute a few percent of the US annual mean tropospheric $\mathrm{NO}_{2}$ column. Similarly, $\mathrm{NO}_{\mathrm{x}}$ production by lightning is stronger in summer, with an estimated annual contribution of $15 \%$ to the total emissions. Because the 
218 discrepancies between the OMI retrieveals and the EPA's emission estimates lack a clear seasonal

219 dependence (see Figures 1d-e), we expect negligible contributions from soil and lightning $\mathrm{NO}_{\mathrm{x}}$

220 emissions to the enhanced tropospheric $\mathrm{NO}_{2}$ in the period of 2009-2015. Furthermore, Figure 4

221 indicates that the flash rate density over North America from LIS is uncorrelated with the observed

$222 \mathrm{NO}_{2}$ variation.

\section{$223 \quad 3.2$ Time dependent OMI retrieval errors (H2)}

The quality of the OMI retrievals has been evaluated with surface in-situ measurements.

Lamsal et al. (2015) reported that the correlation between $\mathrm{OMI} \mathrm{NO}_{2}$ tropospheric columns (NASA)

and the AQS surface in-situ $\mathrm{NO}_{2}$ measurements was 0.68 for the period 2005-2010. Hoek et al.

(2015) indicated that the correlation between the $\mathrm{OMI} \mathrm{NO}_{2}$ tropospheric columns (DOMINO) and

surface in-situ measurements in the Netherlands was 0.74 at 2007 . The stability of our analysis based on OMI retrievals (NASA and DOMINO) is ensured by the strict quality filters; these ensure that changes in OMI sampling due to detector problems (e.g. row anomaly) do not affect our conclusions.

Figure 5 shows the annual slopes of tropospheric $\mathrm{NO}_{2}$ columns from OMI (NASA and DOMINO) over the period of 2005-2015. Both OMI products (NASA and DOMINO), with various a priori models (GMI and TM4) and algorithms, show consistent variations over the northern Pacific Ocean and the western US: insignificant changes in the period 2005-2008 (Figure 5a-b), positive changes in the period 2009-2012 (Figure 5c-d) and insignificant changes in the period 2013-2015 (Figure 5e-f). Using the Berkeley High-Resolution (BEHR) $\mathrm{NO}_{2}$ product for OMI, Russell et al. (2012) obtained similar positive change over the western US with the Weather 
OMI $\mathrm{NO}_{2}$ over the period of 2005-2015 are not caused by systematic biases.

While our adherence to published data quality filters should ensure the observed OMI based $\mathrm{NO}_{2}$ values are robust, we note as a caveat that we cannot unequivocally confirm these changes with independent data due to a lack of either total column or free-tropospheric $\mathrm{NO}_{2}$ measurements over the observed region. For example, Mt. Bachelor Observatory (MBO) station has free troposheric $\mathrm{NO}_{2}$ observations in the period of 2005-2009 and the CARIBIC aircraft measurements only provide free tropospheric $\mathrm{NO}_{2}$ observations over the US since 2014. Using remotely sensed $\mathrm{NO}_{2}$ measurements from the Global Ozone Monitoring Experiment-2 (GOME2), Miyazaki et al. (2017) found a slight increase of tropospheric $\mathrm{NO}_{2}$ columns over the US in the

250 period of 2009-2012, consistent with our result. However, a significant sudden decrease of retrieved tropospheric $\mathrm{NO}_{2}$ columns from GOME-2 has been observed since July 2013, associated with the change in the measurement mode (http://projects.knmi.nl/atcom/news.php?id=44).

\subsection{Non-local sources (H3)}

We have demonstrated that hypotheses $\mathrm{H} 1$ and $\mathrm{H} 2$ are not likely the dominant factors, which leaves hypothesis H3 (non-local sources) as possible important contributors. Figures 5g-h show the annual slope of tropospheric $\mathrm{NO}_{2}$ columns (percent base) from OMI (NASA and DOMINO) over the period of 2009-2015. Our analysis demonstrates a significant positive change over the northern Pacific Ocean during this time period, and an insignificant but positive change over the western US, suggesting possible contributions from transpacific transport to tropospheric $\mathrm{NO}_{2}$ over the western US. Over the period of 2005-2008, the lack of change in tropospheric $\mathrm{NO}_{2}$ columns over the northern Pacific Ocean (Figure 5a-b) indicates the dominant role of local sources 
with the appearance of a discrepancy between the OMI retrievals and EPA's emission estimates

(Figure 1c). Accompanying with the observed decrease of Chinese $\mathrm{NO}_{2}$ emissions (Figure 1b), no

266 significant change is observed over the northern Pacific Ocean over the period of 2013-2015

267 (Figure 5e-f).

Decadal climate variability has non-negligible influences on tropospheric compositions by

affecting the physical and chemical processes. For example, Lin et al. (2014) indicated that transpacific transport of $\mathrm{O}_{3}$ is modulated by decadal variability of El Niño-Southern Oscillation (ENSO). El Niño is defined as the appearance of anomalously warm water off northern Peru and Ecuador in December. The atmospheric component tied to El Niño is called the Southern Oscillation (Trenberth 1997). To the best of our understanding, ENSO is the dominant climate phenomenon linked to extreme weather conditions globally (Cai et al. 2015), and it also exerts a major influence on the interannual variability of $\mathrm{O}_{3}$ in the troposphere (Doherty et al., 2006). Following Jiang et al. (2016b), we conducted an analysis using an idealized passive tracer to assess the possible influences of transport patterns. We performed a GEOS-Chem model simulation for tropospheric $\mathrm{NO}_{2}$ over the period of 2005-2015 with an $\mathrm{NO}_{2}$-like tracer with a constant 15-day lifetime and fixed (2005 level) surface $\mathrm{NO}_{\mathrm{x}}$ emissions. The passive tracer simulation with constant lifetime avoids the possible influences from uncertainties in the modeled nonlinear $\mathrm{NO}_{\mathrm{x}}$ chemistry, particularly, the conversion between $\mathrm{NO}_{\mathrm{x}}$ and its longer-lived reservior species.

Figures 6a-c show that even with emissions held constant, interannual variations in transport produce differences in $\mathrm{NO}_{2}$ (or the passive tracer) columns over the eastern Pacific. Based on the passive tracer simulation, transpacific transport decreased over the period of 20052008 (Figure 5a). During this four-year period, declining transport efficiency appears to have offset the increase of Asian emissions, resulting in insignificant changes of tropospheric $\mathrm{NO}_{2}$ columns 
over the northern Pacific Ocean (Figures 5a-b), and consequently, good agreement between the OMI retrievals and the EPA's emission estimates (Figure 1c). The efficiency of transpacific transport is more stable over the period of 2009-2012 (Figure 6b), which allows stronger transpacific transport of rising Asian emissions. It leads to positive changes of tropospheric $\mathrm{NO}_{2}$

291 columns over the northern Pacific Ocean (Figure 5c-d), and consequent growing discrepancy 292 between the OMI retrievals and the EPA's emission estimates (Figure 1c). Increasing efficiency 293 in transpacific transport over the period of 2013-2015 (Figure 6c) counteracts the decrease of 294 Chinese $\mathrm{NO}_{2}$ (Figure 1b), again resulting in no change in the tropospheric $\mathrm{NO}_{2}$ column over northern Pacific Ocean (Figure 5e-f) and relatively flat changes in US tropospheric $\mathrm{NO}_{2}$ column.

296 Figure 6d shows the comparison between regional mean of passive tracer columns over the 297 northern Pacific Ocean with the NOAA Niño 3.4 index. There is strong correlation between transpacific transport and ENSO: the transpacific transport is stronger in El Niño years and weaker in La Niña years, demonstrating strong influence of decadal climate variability on the transpacific transport. primarily in the lower/middle troposphere in winter and spring, and primarily in the middle/upper troposphere in summer and fall, but that differences in tropospheric column remain small for different seasons. Figure 7 shows the seasonal mean tropospheric columns for the $\mathrm{NO}_{2}$-like tracer between 2005-2015. Our analysis indicates the transpacific transport, with constant 15-day lifetime, is strongest in summer and spring. However, the lifetime of PAN approximately doubles for every $4^{\circ} \mathrm{C}$ decrease in temperature. Consequently, due to the temperature effect associated with the 
310 Similarly, the actual transpacific transport of $\mathrm{NO}_{2}$ in winter, relative to that in spring, should be

311 greater than shown in Figure $7 \mathrm{~d}$ because of the temperature differences between winter and spring.

312 Thus, in agreement with Brown-Steiner et al. (2011), our analysis would suggest weak seasonality

313 of transpacific transport of reactive nitrogen, consistent with the observed changes in $\mathrm{OMI} \mathrm{NO}_{2}$

314 over the US (Figures 1d-e). It should be noticed that our conclusion about weak seasonality of

315 transpacific transport is different from previous studies (e.g. Liang et al. 2004) based on carbon

316 monoxide (CO) simulations. The discrepancy in the seasonality is associated with the strong

317 springtime biomass burning CO emissions in southeast and boreal Asia, whereas the contribution

318 of biomass burning to tropospheric $\mathrm{NO}_{\mathrm{x}}$ is relatively small.

\section{4. Conclusions}

In this work, we investigated the variation of US tropospheric $\mathrm{NO}_{2}$ in the past decade, to evaluate the contribution of non-local sources to the tropospheric $\mathrm{NO}_{\mathrm{x}}$ budget. We demonstrated significant divergence between the time variation in tropospheric $\mathrm{NO}_{2}$ columns from the $\mathrm{OMI}$ retrievals and the EPA's $\mathrm{NO}_{\mathrm{x}}$ emission estimates. Our analysis suggests limited contributions from local effects such as fossil fuel emissions, lightning, or instrument artifacts, and indicates possible important contributions from long-range transport of Asian emissions that are modulated by ENSO. Passive tracer simulation with fixed emissions demonstrates that the intensity of transpacific transport is stronger in El Niño years and weaker in La Niña years. The unexpected important contributions from long-range transport contradict assumptions of weak long-range transport for $\mathrm{NO}_{\mathrm{x}}$, suggesting potential underestimation of transported reactive nitrogen in the state of the art models.

In related studies, long-term free tropospheric $\mathrm{O}_{3}$ observations over Europe demonstrated 

transport of $\mathrm{NO}_{\mathrm{x}}$ could potentially reconcile the large discrepancy between modeled and observed

335 free tropospheric $\mathrm{O}_{3}$ over Europe. Because of uncertain processes in the long-range transport of 336 reactive nitrogen (Ye et al. 2016) and the dominant role of long lifetime reservoirs (Bertram et al.

337 2013), we are not able to quantify the different contributions to the observed tropospheric $\mathrm{NO}_{\mathrm{x}}$ in

338 this study. This quantification will require comprehensive observations and modeling efforts to

339 understand the formation and transport of long lifetime reservoirs of reactive nitrogen.

340

341 Acknowledgments: We acknowledge the $\mathrm{OMI}$ tropospheric $\mathrm{NO}_{2}$ column data from www.temis.nl 342 and disc.sci.gsfc.nasa.gov. We acknowledge the flash rate density data from ghrc.nsstc.nasa.gov.

343 We thank the Environmental Protection Agency for providing their national $\mathrm{NO}_{\mathrm{x}}$ emission data 344 and surface in-situ $\mathrm{NO}_{2}$ measurements. We thank the Environment Canada for providing their 345 surface in-situ $\mathrm{NO}_{2}$ measurements. We thank Lee Murray for useful discussions. The National 346 Center for Atmospheric Research (NCAR) is sponsored by the National Science Foundation. Part 347 of this work was carried out at the Jet Propulsion Laboratory, California Institute of Technology, 348 under a contract with the National Aeronautics and Space Administration. Support for Emily V. 349 Fischer and Liye Zhu was provided by NASA Award Number NNX14AF14G. Support for Daven $350 \quad$ K. Henze was provided by NASA HAQAST.

\section{Reference:}

353 Bertram, T., Perring, A., Wooldridge, P., Dibb, J., Avery, M. and Cohen, R.: On the export of 354 reactive nitrogen from Asia: NOx partitioning and effects on ozone, Atmos Chem Phys, 13(9), 4617-4630, doi:10.5194/acp-13-4617-2013, 2013. 
Boersma, K., Eskes, H., Dirksen, R., A, R., Veefkind, J., Stammes, P., Huijnen, V., Kleipool, Q., Sneep, M., Claas, J., Leitão, J., Richter, A., Zhou, Y. and Brunner, D.: An improved tropospheric NO2 column retrieval algorithm for the Ozone Monitoring Instrument, Atmospheric Meas Techniques, 4(9), 1905-1928, doi:10.5194/amt-4-1905-2011, 2011.

Brown- Steiner, B. and Hess, P.: Asian influence on surface ozone in the United States: A comparison of chemistry, seasonality, and transport mechanisms, J Geophys Res Atmospheres 116, D17309, doi:10.1029/2011JD015846, 2011.

Bucsela, E., Krotkov, N., Celarier, E., Lamsal, L., Swartz, W., Bhartia, P., Boersma, K., Veefkind, J., Gleason, J. and Pickering, K.: A new stratospheric and tropospheric NO2 retrieval algorithm for nadir-viewing satellite instruments: applications to OMI, Atmospheric Meas Techniques, 6(10), 2607-2626, doi:10.5194/amt-6-2607-2013, 2013.

Cai, W., Santoso, A., Wang, G., Yeh, S.-W., An, S.-I., Cobb, K., Collins, M., Guilyardi, E., Jin, F.-F., Kug, J.-S., Lengaigne, M., McPhaden, M., Takahashi, K., Timmermann, A., Vecchi, G., Watanabe, M. and Wu, L.: ENSO and greenhouse warming, Nat Clim Change, 5(9), 849-859, doi:10.1038/nclimate2743, 2015.

Cecil, D. J.: LIS/OTD 2.5 Degree Low Resolution Monthly Time Series (LRMTS). Dataset available online from the NASA Global Hydrology Resource Center DAAC, Huntsville, Alabama, U.S.A, 2006.

Cooper, O., Parrish, D., Stohl, A., Trainer, M., Nédélec, P., Thouret, V., Cammas, J., Oltmans, S., Johnson, B., Tarasick, D., Leblanc, T., McDermid, I., Jaffe, D., Gao, R., Stith, J., Ryerson, T., Aikin, K., Campos, T., Weinheimer, A. and Avery, M.: Increasing springtime ozone mixing ratios in the free troposphere over western North America, Nature, 463(7279), 344-348, doi:10.1038/nature08708, 2010. 
Doherty, Stevenson, Johnson, Collins and Sanderson: Tropospheric ozone and El Niño-Southern Oscillation: Influence of atmospheric dynamics, biomass burning emissions, and future climate change, J Geophys Res Atmospheres, 111, D19304, doi:10.1029/2005JD006849, 2006.

Duncan, B., Lamsal, L., Thompson, A., Yoshida, Y., Lu, Z., Streets, D., Hurwitz, M. and Pickering, K.: A space-based, high-resolution view of notable changes in urban NOx pollution around the world (2005-2014), J Geophys Res Atmospheres, 121(2), 976-996, doi:10.1002/2015JD024121, 2016.

Fischer, E., Jacob, D., Yantosca, R., Sulprizio, M., Millet, D., Mao, J., Paulot, F., Singh, H., Roiger, A., Ries, L., Talbot, R. W., Dzepina, K. and Deolal, S.: Atmospheric peroxyacetyl nitrate (PAN): a global budget and source attribution, Atmos Chem Phys, 14(5), 2679-2698, doi:10.5194/acp-14-2679-2014, 2014.

Gu, D., Wang, Y., Smeltzer, C. and Boersma, K.: Anthropogenic emissions of NOx over China: Reconciling the difference of inverse modeling results using GOME-2 and OMI measurements, J Geophys Res Atmospheres, 119(12), 7732-7740, doi:10.1002/2014JD021644, 2014.

Hoek, G., Eeftens, M., Beelen, R., Fischer, P., Brunekreef, B., Boersma, K. and Veefkind, P.: Satellite NO2 data improve national land use regression models for ambient NO2 in a small densely populated country, Atmos Environ, 105, 173-180, doi:10.1016/j.atmosenv.2015.01.053, 2015.

Hudman, Russell, Valin and Cohen: Interannual variability in soil nitric oxide emissions over the United States as viewed from space, Atmos Chem Phys, 10(20), 9943-9952, doi:10.5194/acp10-9943-2010, 2010.

Itahashi, S., Uno, I., Irie, H., Kurokawa, J.-I. and Ohara, T.: Regional modeling of tropospheric NO2 vertical column density over East Asia during the period 2000-2010: comparison with 

2014, 2014.

Jaeglé, L., Steinberger, L., Martin, R. and Chance, K.: Global partitioning of $\mathrm{NO}_{\mathrm{x}}$ sources using satellite observations: Relative roles of fossil fuel combustion, biomass burning and soil emissions, Faraday Discuss, 130(0), 407-423, doi:10.1039/B502128F, 2005.

Jiang, Z., Worden, J., Payne, V., Zhu, L., Fischer, E., Walker, T. and Jones, D.: Ozone export from doi:10.1002/2016JD024952, 2016a.

Jiang, Z., Miyazaki, K., Worden, J., Liu, J., Jones, D. and Henze, D.: Impacts of anthropogenic and natural sources on free tropospheric ozone over the Middle East, Atmos Chem Phys, 16(10), 6537-6546, doi:10.5194/acp-16-6537-2016, $2016 \mathrm{~b}$.

Kharol, S. K., Martin, R. V., Philip, S., Boys, B., Lamsal, L. N., Jerrett, M., Brauer, M., Crouse, D. L., McLinden, C. and Burnett, R. T.: Assessment of the magnitude and recent trends in satellite-derived ground-level nitrogen dioxide over North America, Atmos Environ, 118, 236 245, doi:10.1016/j.atmosenv.2015.08.011, 2015.

Krotkov, N. A. and Veefkind, P.: OMI/Aura Nitrogen Dioxide $\left(\mathrm{NO}_{2}\right)$ Total and Tropospheric

418 Column 1-orbit L2 Swath 13x24 km V003, Greenbelt, MD, USA, Goddard Earth Sciences 419 Data and Information Services Center (GES DISC), 2006.

420 Krotkov, N., McLinden, C., Li, C., Lamsal, L., Celarier, E., Marchenko, S., Swartz, W., Bucsela, 421 E., Joiner, J., Duncan, B., Boersma, K., Veefkind, J., Levelt, P., Fioletov, V., Dickerson, R., $422 \mathrm{He}, \mathrm{H} ., \mathrm{Lu}, \mathrm{Z}$. and Streets, D.: Aura OMI observations of regional $\mathrm{SO}_{2}$ and $\mathrm{NO}_{2}$ pollution 423 changes from 2005 to 2015, Atmos Chem Phys, 16(7), 4605-4629, doi:10.5194/acp-16-4605$424 \quad 2016,2016$. 

anthropogenic NOx emission inventories, Geophys Res Lett, 38, L05810, doi:10.1029/2010GL046476, 2011. trends (2005-2013): EPA Air Quality System (AQS) data versus improved observations from the Ozone Monitoring Instrument (OMI), Atmos Environ, 110, 130-143, doi:10.1016/j.atmosenv.2015.03.055, 2015.

Liang, Q., Jaeglé, L., Jaffe, D., Weiss-Penzias, P., Heckman, A. and Snow, J.: Long-range transport of Asian pollution to the northeast Pacific: Seasonal variations and transport pathways of carbon monoxide, J Geophys Res Atmospheres 109, D23S07, doi:10.1029/2003JD004402, 2004.

Lin, M., Horowitz, L., Oltmans, S., Fiore, A. and Fan, S.: Tropospheric ozone trends at Mauna Loa Observatory tied to decadal climate variability, Nat Geosci, 7(2), 136-143, doi:10.1038/ngeo2066, 2014.

Liu, F., Zhang, Q., A, R., Zheng, B., Tong, D., Yan, L., Zheng, Y. and He, K.: Recent reduction in NO x emissions over China: synthesis of satellite observations and emission inventories,

443 Logan, J., Staehelin, J., Megretskaia, I., Cammas, J. -P., Thouret, V., Claude, H., Backer, H., 444 Steinbacher, M., Scheel, H. -E., Stübi, R., Fröhlich, M. and Derwent, R.: Changes in ozone over Europe: Analysis of ozone measurements from sondes, regular aircraft (MOZAIC) and alpine surface sites, J Geophys Res Atmospheres 117, D09301, doi:10.1029/2011JD016952, 
448 Martin, R., Jacob, D., Chance, K., Kurosu, T., Palmer, P. and Evans, M.: Global inventory of nitrogen oxide emissions constrained by space-based observations of NO2 columns, J Geophys Res Atmospheres 108(D17), 4537, doi:10.1029/2003JD003453, 2003.

Mijling, B. and A, R.: Using daily satellite observations to estimate emissions of short-lived air pollutants on a mesoscopic scale, J Geophys Res Atmospheres 117, D17302, doi:10.1029/2012JD017817, 2012.

Miyazaki, K., Eskes, H., Sudo, K., Boersma, K., Bowman, K. and Kanaya, Y.: Decadal changes in global surface NOx emissions from multi-constituent satellite data assimilation, Atmos Chem Phys, 17(2), 807-837, doi:10.5194/acp-17-807-2017, 2017.

Parrish, D., Law, K., Staehelin, J., Derwent, R., Cooper, O., Tanimoto, H., Volz-Thomas, A., Gilge, baseline ozone concentrations at northern mid-latitudes, Atmos Chem Phys, 12(23), 11485-

Parrish, D., Lamarque, J. -F., Naik, V., Horowitz, L., Shindell, D., Staehelin, J., Derwent, R., Cooper, O., Tanimoto, H., Volz-Thomas, A., Gilge, S., Scheel, H. -E., Steinbacher, M. and Fröhlich, M.: Long-term changes in lower tropospheric baseline ozone concentrations: Comparing chemistry-climate models and observations at northern midlatitudes, J Geophys Res Atmospheres, 119(9), 5719-5736, doi:10.1002/2013JD021435, 2014.

Reuter, Buchwitz, Hilboll, Richter, Schneising, Hilker, Heymann, Bovensmann and Burrows: Decreasing emissions of $\mathrm{NOx}$ relative to $\mathrm{CO} 2$ in East Asia inferred from satellite observations, Nat Geosci, 7(11), 792-795, doi:10.1038/ngeo2257, 2014.

Russell, A., Valin, L. and Cohen, R.: Trends in OMI NO2 observations over the United States: 
472 Schumann U, Huntrieser H (2007) The global lightning-induced nitrogen oxides source.

Atmos Chem Phys 7(14):3823\{3907, doi:10.5194/acp-7-3823-2007.

Skowron, A., Lee, D. and León, R.: Variation of radiative forcings and global warming potentials from regional aviation NOx emissions, Atmos Environ, 104, 69-78, doi:10.1016/j.atmosenv.2014.12.043, 2015.

Tong, D., Lamsal, L., Pan, L., Ding, C., Kim, H., Lee, P., Chai, T., Pickering, K. and Stajner, I.: Long-term NOx trends over large cities in the United States during the great recession: Comparison of satellite retrievals, ground observations, and emission inventories., Atmos Environ 107, 70-84, 2015.

Trenberth, K. E.: The Definition of El Niño, Bulletin of the American Meteorological Society, 78(12), 2771-2777, 1997.

van der A, R. J., Mijling, B., Ding, J., Koukouli, M. E., Liu, F., Li, Q., Mao, H., and Theys, N.: Cleaning up the air: effectiveness of air quality policy for $\mathrm{SO}_{2}$ and $\mathrm{NO}_{x}$ emissions in China, Atmos. Chem. Phys., 17, 1775-1789, doi:10.5194/acp-17-1775-2017, 2017.

Verstraeten, W., Neu, J., Williams, J., Bowman, K., Worden, J. and Boersma, K.: Rapid increases

Ye, C., Zhou, X., Pu, D., Stutz, J., Festa, J., Spolaor, M., Tsai, C., Cantrell, C., Mauldin, R., 490 Campos, T., Weinheimer, A., Hornbrook, R., Apel, E., Guenther, A., Kaser, L., Yuan, B., Karl, T., Haggerty, J., Hall, S., Ullmann, K., Smith, J., Ortega, J. and Knote, C.: Rapid cycling of reactive nitrogen in the marine boundary layer, Nature, 532(7600), 489-491, doi:10.1038/nature17195, 2016. 


\section{Tables and Figures}

496 Figure 1. (a-b): monthly mean (dash lines) and annual mean (solid lines) tropospheric $\mathrm{NO}_{2}$ column 497 over contiguous United States and East China from OMI (NASA and DOMINO) products; (c-e): 498 percent changes of annual mean (c) and seasonal mean (d-e) tropospheric $\mathrm{NO}_{2}$ column over the US from the OMI and EPA's emission estimates, normalized at 2009.

Figure 2. Schematic figure showing the sources of tropospheric $\mathrm{NO}_{\mathrm{x}}$.

Figure 3. (a) difference of mean $\mathrm{NO}_{2}$ concentrations of surface in-situ measurements (AQS and NAPS stations) from 2009-2010 to 2014-2015; Blue (red) means decrease (increase) of $\mathrm{NO}_{2}$ concentrations. (b) same as panel a, but averaged with $4^{\circ} \times 5^{\circ}$ resolution.

Figure 4. Flash rate density $\left(1 \times 10^{-3}\right.$ flash $\left./ \mathrm{km}^{2} / \mathrm{month}\right)$ over North America $\left(15^{\circ} \mathrm{N}-42.5^{\circ} \mathrm{N}, 130^{\circ} \mathrm{W}\right.$ $60^{\circ} \mathrm{W}$ ) from Lightning Imaging Sensor (LIS).

Figure 5. (a-f) annual slope of tropospheric $\mathrm{NO}_{2}$ column (unit $1 \times 10^{15} \mathrm{molec} / \mathrm{cm}^{2}$ ) from OMI

Figure 6. (a-c) Annual slope of passive tracer column (percent base). The passive tracer is simulated with GEOS-Chem model with constant 15-day lifetime. The surface $\mathrm{NO}_{\mathrm{x}}$ emissions are fixed at 2005 level. The lightning $\mathrm{NO}_{\mathrm{x}}$ emissions are not included in the simulation. (d) Blue line: regional mean (box in panel a) of passive tracer column, normalized by the 11-year mean (20052015). The black line shows the NOAA Niño 3.4 index.

Figure 7. Seasonal mean passive tracer column (2005-2015), with $10^{16}$ molec $\mathrm{cm}^{-2}$. The passive tracer is simulated with GEOS-Chem model with constant 15-day lifetime. The surface $\mathrm{NO}_{\mathrm{x}}$ emissions are fixed at 2005 level. It should be noticed that the actual transpacific transport of reactive nitrogen in fall and winter is stronger than panels $\mathrm{c}-\mathrm{d}$ due to the decrease of temperature. 
Atmos. Chem. Phys. Discuss., https://doi.org/10.5194/acp-2017-382

Manuscript under review for journal Atmos. Chem. Phys.

Discussion started: 6 June 2017

(c) Author(s) 2017. CC BY 3.0 License.

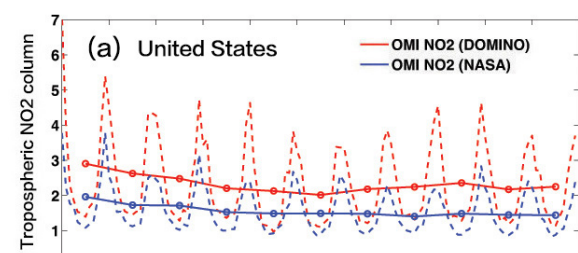

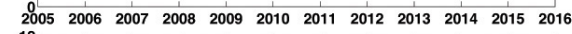

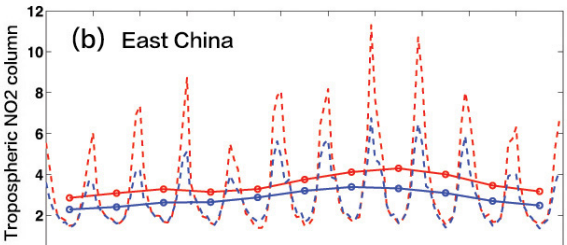

$\begin{array}{llllllllllll}2005 & 2006 & 2007 & 2008 & 2009 & 2010 & 2011 & 2012 & 2013 & 2014 & 2015 & 2016\end{array}$

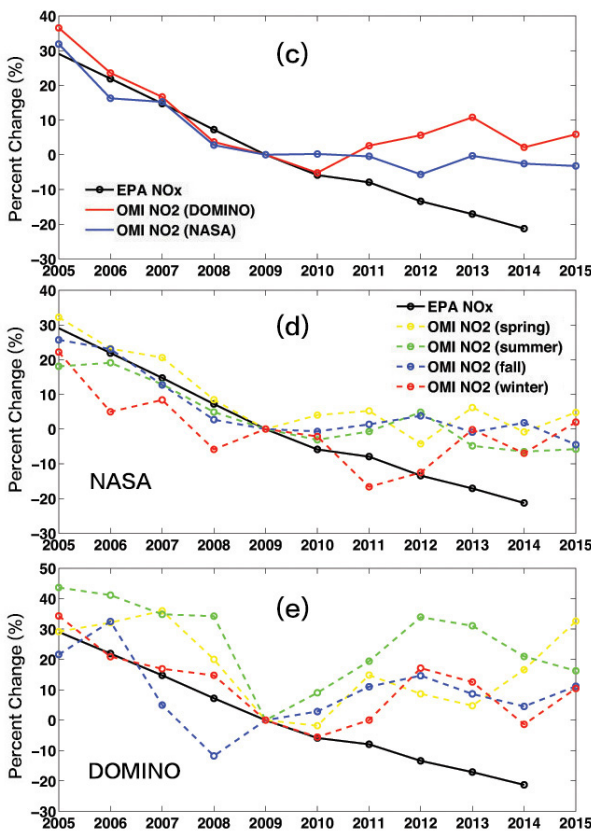

Figure 1. (a-b): monthly mean (dash lines) and annual mean (solid lines) tropospheric $\mathrm{NO}_{2}$ column over contiguous United States and East China from OMI (NASA and DOMINO) products; (c-e): percent changes of annual mean (c) and seasonal mean (d-e) tropospheric $\mathrm{NO}_{2}$ column over the US from the OMI and EPA's emission estimates, normalized at 2009.

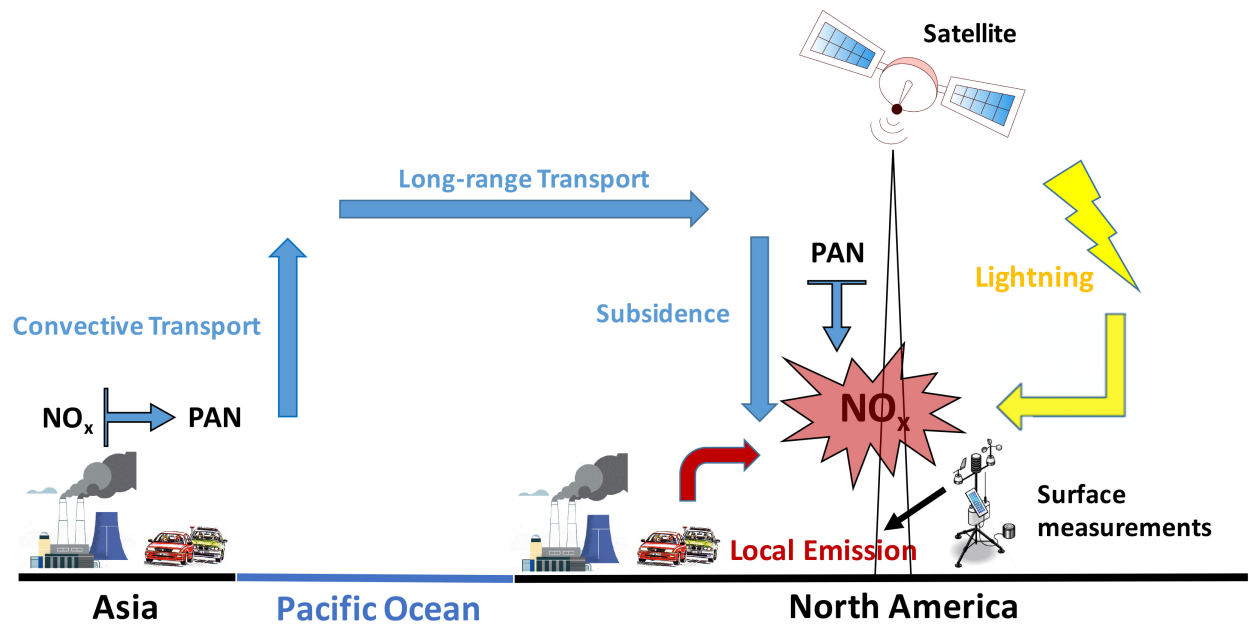

Figure 2. Schematic figure showing the sources of tropospheric $\mathrm{NO}_{\mathrm{x}}$. 
Atmos. Chem. Phys. Discuss., https://doi.org/10.5194/acp-2017-382

Manuscript under review for journal Atmos. Chem. Phys.

Discussion started: 6 June 2017

(C) Author(s) 2017. CC BY 3.0 License.
Atmospheric

Chemistry

and Physics

Discussions
533

534

535

536

537

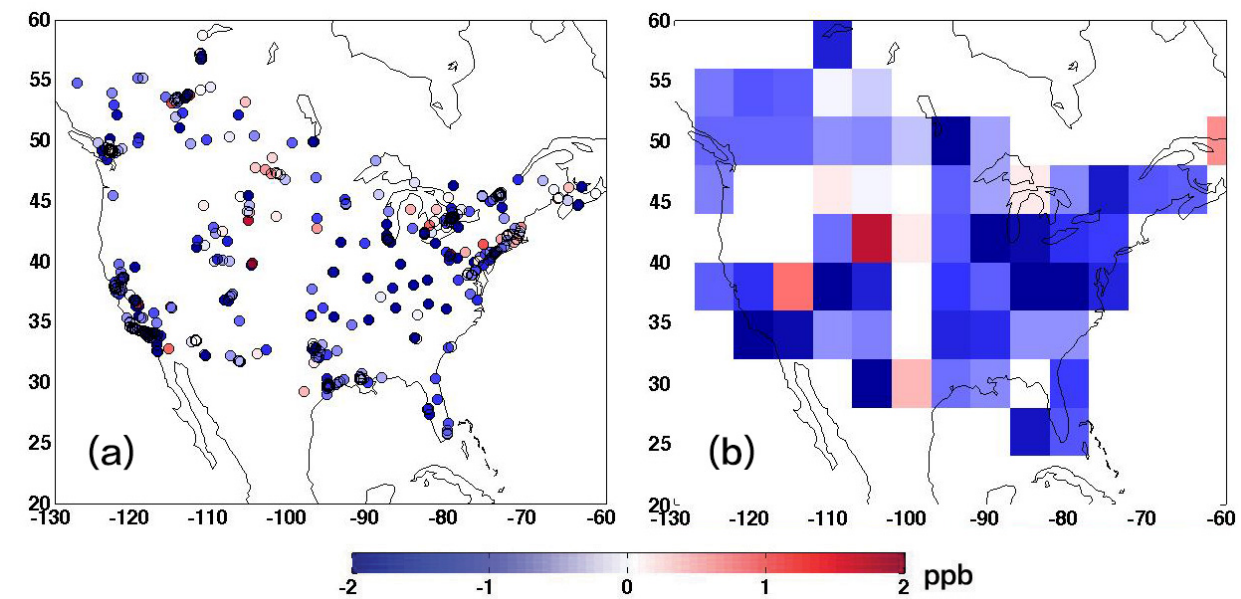

Figure 3. (a) difference of mean $\mathrm{NO}_{2}$ concentrations of surface in-situ measurements (AQS and NAPS stations) from 2009-2010 to 2014-2015; Blue (red) means decrease (increase) of $\mathrm{NO}_{2}$ concentrations. (b) same as panel a, but averaged with $4^{\circ} \times 5^{\circ}$ resolution.

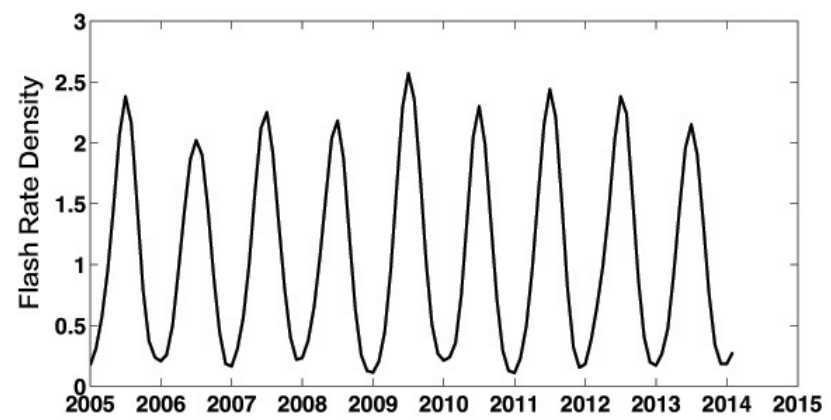

Figure 4. Flash rate density $\left(1 \times 10^{-3}\right.$ flash $\left./ \mathrm{km}^{2} / \mathrm{month}\right)$ over North America $\left(15^{\circ} \mathrm{N}-42.5^{\circ} \mathrm{N}\right.$, $130^{\circ} \mathrm{W}-60^{\circ} \mathrm{W}$ ) from Lightning Imaging Sensor (LIS). 
Atmos. Chem. Phys. Discuss., https://doi.org/10.5194/acp-2017-382

Manuscript under review for journal Atmos. Chem. Phys.

Discussion started: 6 June 2017

(c) Author(s) 2017. CC BY 3.0 License.
Atmospheric

Chemistry

and Physics

Discussions (c) (1)
555
556
557
558
559
560
561
562
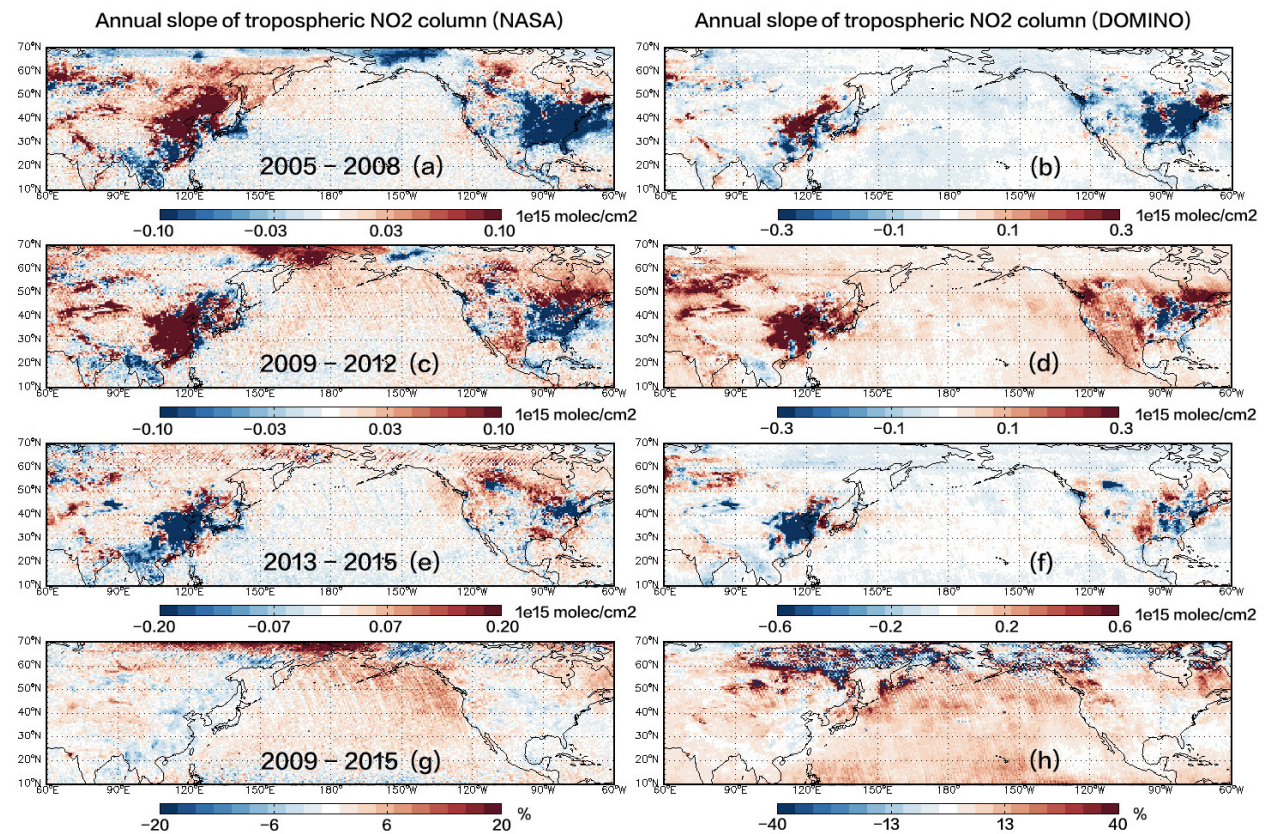

Figure 5. (a-f) annual slope of tropospheric $\mathrm{NO}_{2}$ column (unit $1 \times 10^{15} \mathrm{molec} / \mathrm{cm}^{2}$ ) from OMI (NASA and DOMINO products); (g-h) same as panels a-f, with percent (\%) as unit. 
Atmos. Chem. Phys. Discuss., https://doi.org/10.5194/acp-2017-382

Manuscript under review for journal Atmos. Chem. Phys.

Discussion started: 6 June 2017

(c) Author(s) 2017. CC BY 3.0 License.
Atmospheric

Chemistry

and Physics

Discussions

(c) $($ i)

580

581

582

583

584

585

Annual slope of passive tracer column
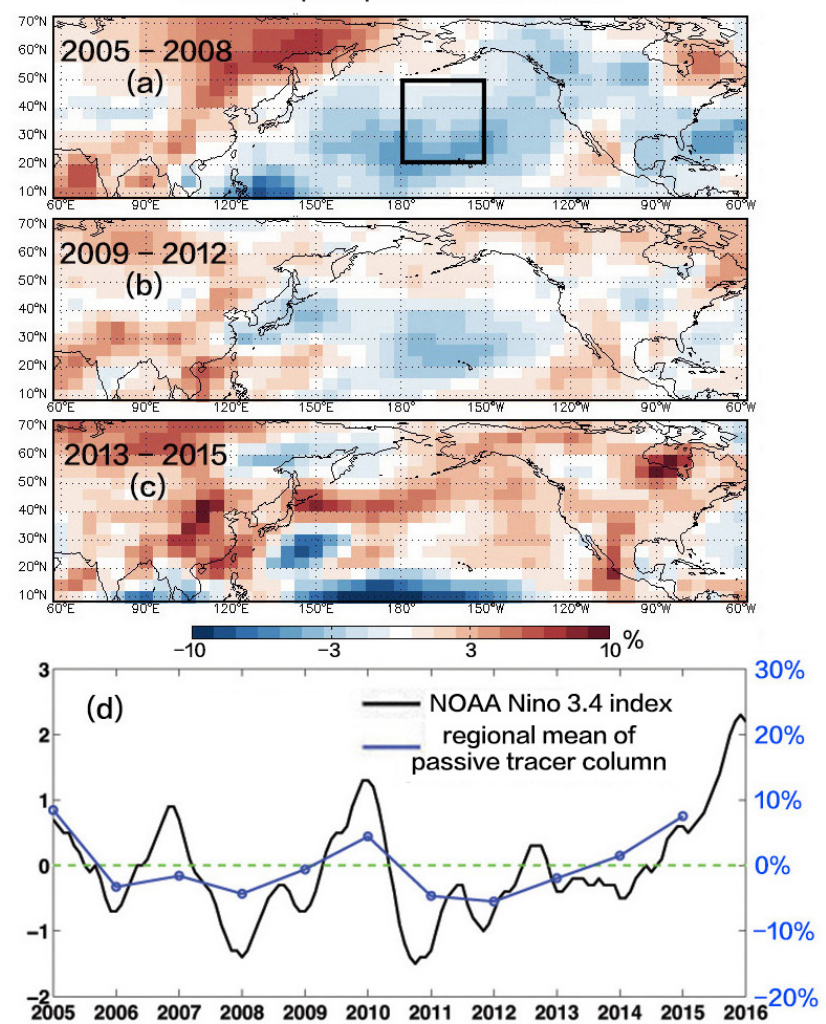

Figure 6. (a-c) Annual slope of passive tracer column (percent base). The passive tracer is simulated with GEOS-Chem model with constant 15-day lifetime. The surface $\mathrm{NO}_{\mathrm{x}}$ emissions are fixed at 2005 level. The lightning $\mathrm{NO}_{\mathrm{x}}$ emissions are not included in the simulation. (d) Blue line: regional mean (box in panel a) of passive tracer column, normalized by the 11-year mean (2005-2015). The black line shows the NOAA Niño 3.4 index. 
Atmos. Chem. Phys. Discuss., https://doi.org/10.5194/acp-2017-382

Manuscript under review for journal Atmos. Chem. Phys.

Discussion started: 6 June 2017

(c) Author(s) 2017. CC BY 3.0 License.
Atmospheric

Chemistry

and Physics

Discussions

(c) (1)


Figure 7. Seasonal mean passive tracer column (2005-2015), with $10^{16} \mathrm{molec} \mathrm{cm}^{-2}$. The passive tracer is simulated with GEOS-Chem model with constant 15-day lifetime. The surface $\mathrm{NO}_{\mathrm{x}}$ emissions are fixed at 2005 level. It should be noticed that the actual transpacific transport of reactive nitrogen in fall and winter is stronger than panels $\mathrm{c}-\mathrm{d}$ due to the decrease of temperature. 